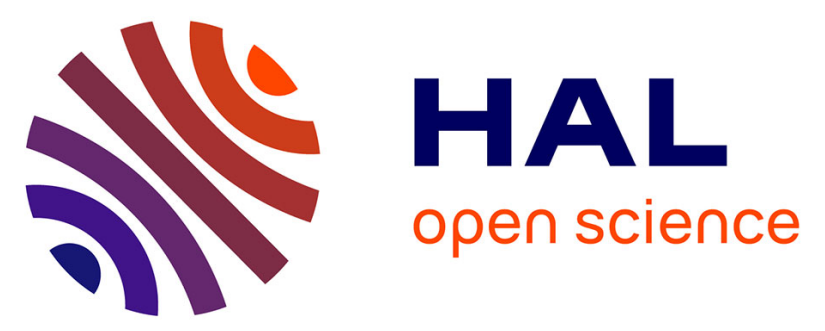

\title{
10,000 years of vegetation history of the Aa palaeoestuary, St-Omer Basin, northern France
}

Emmanuel Gandouin, Philippe Ponel, Valérie Andrieu-Ponel, Frédéric Guiter, Jacques-Louis de Beaulieu, M. Djamali, Evelyne Franquet, Brigitte van Vliet-Lanoë, M. Alvitre, Murielle Meurisse, et al.

\section{To cite this version:}

Emmanuel Gandouin, Philippe Ponel, Valérie Andrieu-Ponel, Frédéric Guiter, Jacques-Louis de Beaulieu, et al.. 10,000 years of vegetation history of the Aa palaeoestuary, St-Omer Basin, northern France. Review of Palaeobotany and Palynology, 2009, 156 (3-4), pp.307-318. 10.1016/j.revpalbo.2009.03.008 . insu-00445923

\section{HAL Id: insu-00445923 \\ https://hal-insu.archives-ouvertes.fr/insu-00445923}

Submitted on 8 Oct 2020

HAL is a multi-disciplinary open access archive for the deposit and dissemination of scientific research documents, whether they are published or not. The documents may come from teaching and research institutions in France or abroad, or from public or private research centers.
L'archive ouverte pluridisciplinaire HAL, est destinée au dépôt et à la diffusion de documents scientifiques de niveau recherche, publiés ou non, émanant des établissements d'enseignement et de recherche français ou étrangers, des laboratoires publics ou privés. 


\title{
GANDOUIN E., PONEL P., ANDRIEU-PONEL V., GUITER F., BEAULIEU J-L., DJAMALI M., FRANQUET E., VAN VLIET-LANOË B., ALVITRE M., MEURISSE M., BROCANDEL M. \& J. BRULHET 2009. 10,000 years of vegetation history of the Aa palaeoestuary, St-Omer Basin, northern France. Review of Palaeobotany and Palynology 156:307-318.
}

\begin{abstract}
a b s t r a c t

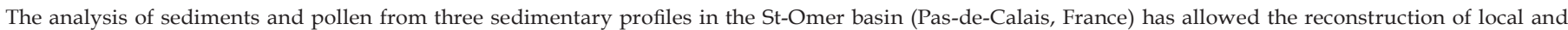

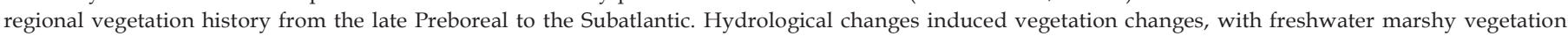

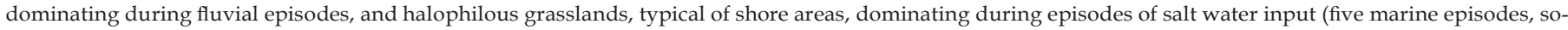

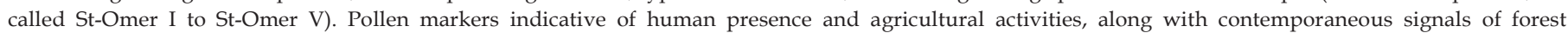
disturbance, are recorded from ca 4000 cal BP onwards.
\end{abstract}

\section{Introduction}

Influence of past climate changes, sea level fluctuations and human disturbances on vegetation organisation are recorded in estuarine sedimentary archives, as shown from the analyses of Holocene deposits in France (e.g., Morzadec-Kerfourn, 1985), Britain (e.g., Waller, 1994; Long et al., 1998; Wimble et al., 2000), Belgium (e.g., Munaut and Paulissen, 1973), Germany (e.g., Freund et al., 2004), the Netherlands (e.g., Bohncke and Vandenberghe, 1991; Törnqvist et al., 2000) and outside Europe (e.g., Angulo et al., 1999; Ybert et al., 2003; Pederson et al., 2005; Yi et al., 2006).

In the North Sea area, reconstructions of sea level and coastline changes from the last glacial maximum have been carried out by Scourse and Austin (1995) and Shennan and Andrews (2000). However, the coastal regions of northern France remain relatively poorly known from a palaeoecological point of view (Ters et al., 1980; Vinchon et al., 2000), despite their key position (near the Pas-de-Calais strait) for the understanding of the marine transgressions that took place in the English Channel and North Sea regions during the Holocene.

During the last 10, 000 years, coastal areas of northwest France were regularly subjected to alternating transgressions/regressions of the English Channel/North Sea Complex (Dubois, 1924; Sommé, 1977).

Such changes are well recorded in the pollen sequences of St-Momelin/Clairmarais and Watten, analyzed respectively by Van der Woude and Roeleveld (1985), and Sommé et al. (1994). These sequences yielded two discontinuous pollen records, starting from the Lower Weichselian, and provided evidence for two main Holocene transgressions, "Calais" and "Dunkerque". These marine transgres-sions have subsequently been subdivided, so as to include more marine episodes within the North Sea basin: Calais I to Calais IV and Dunkerque I to Dunkerque III. The chronological position of each marine episode differs from one region to another according to complex glacio-hydro-eustatic readjustments and neotectonic pro-cesses (Denys and Baeteman, 1995; Lambeck, 1997; Waller and Long, 2003). A chronology for the Flemish-German plain is provided by Behre (2004), but remains undocumented for the St-Omer region until now.

A multidisciplinary programme aimed at reconstructing regional eustatic variations, climatic and environmental changes in the St-Omer basin during the Holocene was launched in 2000. Twenty new sedimentary profiles were sampled for multidisciplinary analyses of sediments, including pollen, moll us c s a $\mathrm{n}$ d i n s e c t s ( C o l e o p t e r a , Trichoptera, and Diptera Chironomidae) (Gandouin, 2003; Gandouin et al., 2005, 2006, 2007a; Ponel et al., 2007). This paper presents a palaeoenvironmental reconstruction of vegetation and landscape successions during the last 10,000 years derived from pollen assemblages from St-Momelin and Watten (Pas-de-Calais). 


\section{Study site}

The St-Omer basin $\left(40 \mathrm{~km}^{2}\right)$ is located in northern France, close to the North Sea, downstream of the Aa river (Fig. 1). The $560 \mathrm{~km}^{2}$ river catchment is predominantly located in a zone of subsidence (Mansy et al., 2003) on a chalk substratum which extends into Eocene clay in its lower part at the St-Omer basin (from Arques to Watten). A single narrow outlet (about $1 \mathrm{~km}$ wide near Watten) connects the large catchment basin and the maritime plain. The gradient of the river along the basin is gentle, only amounting to about $0.1 \mathrm{~m} / \mathrm{km}$. Due to its very low elevation ( $2 \mathrm{~m}$ a.s.l.), the basin served as an estuary during the major episodes of postglacial sea level rise.

Today, the tempered oceanic climate of the St-Omer region is marked by annual rainfall of $c a 800 \mathrm{~mm} / \mathrm{yr}$; the mean temperatures of the warmest and coldest months are about $18{ }^{\circ} \mathrm{C}$ and $3{ }^{\circ} \mathrm{C}$ respectively, and the mean annual temperature is close to $10.5{ }^{\circ} \mathrm{C}$ (Gehu, 1970). The modern landscape is a mosaic of cultivated and built up areas. The marsh was artificially drained during the Medieval period but remnants of peat bogs still persist along the Aa and its tributaries, together with scattered woodlands of willows (Salix cinerea, S. alba, S. fragilis and S. triandra), alder (Alnus glutinosa), poplars (Populus alba and P. tremula), deciduous oaks (e.g., Quercus robur and Q. petraea) and beech (Fagus sylvatica).

\section{Material and methods}

\subsection{Field and laboratory methods}

Profiles S1 (23 m long) and S2 (18 m long) were extracted with an hydraulic piston corer taking core sections of $1 \mathrm{~m}$ long and $10 \mathrm{~cm}$ wide.
Profile P12 was extracted with an auger taking core sections of $1.5 \mathrm{~m}$ long and $15 \mathrm{~cm}$ wide. Sandy sediments from profile S2 were not recovered; these were located at depth comprised between 3 and $6 \mathrm{~m}$.

Pollen extraction was carried out according to Faegri et al. (1989) and Nakagawa (1998). Minerogenic samples were subjected to heavy liquid pollen flotation $(d=1.9)$. A minimum of 300 pollen grains per sample were counted. Pollen frequencies are expressed as a percentage of the total pollen sum of all trees and herbs; helophytic and hydrophytic plants, Pteridophyta and Cyperaceae were excluded from the pollen sum. Alnus pollen was also excluded since it is usually over-represented in sediments from alluvial plains.

A total of 299 samples are presented in the simplified pollen diagrams (Figs. 2-4). "Local Pollen Assemblages Zones" (LPAZ) are identified using percentage changes of at least two significant pollen taxa. "Regional Pollen Assemblage Zones" (RPAZ) are identified using the LPAZ from all three profiles; these allow the main features of regional vegetational change to be depicted (Fig. 5).

\subsection{Radiocarbon dating}

Eighteen sediment samples or wood fragments were dated using the conventional radiocarbon method (Table 1). Some of the dates, previously published by Gandouin et al. $(2005,2006,2007$ a) and Ponel et al. (2007), were calibrated following the INTCAL98 calibration procedure, and using the intercept method (Stuiver et al., 1998). In this paper, calibration has been updated with the INTCAL04 data set (Reimer et al., 2004) using the Calib Rev 5.0 program (Stuiver et al., 2005).

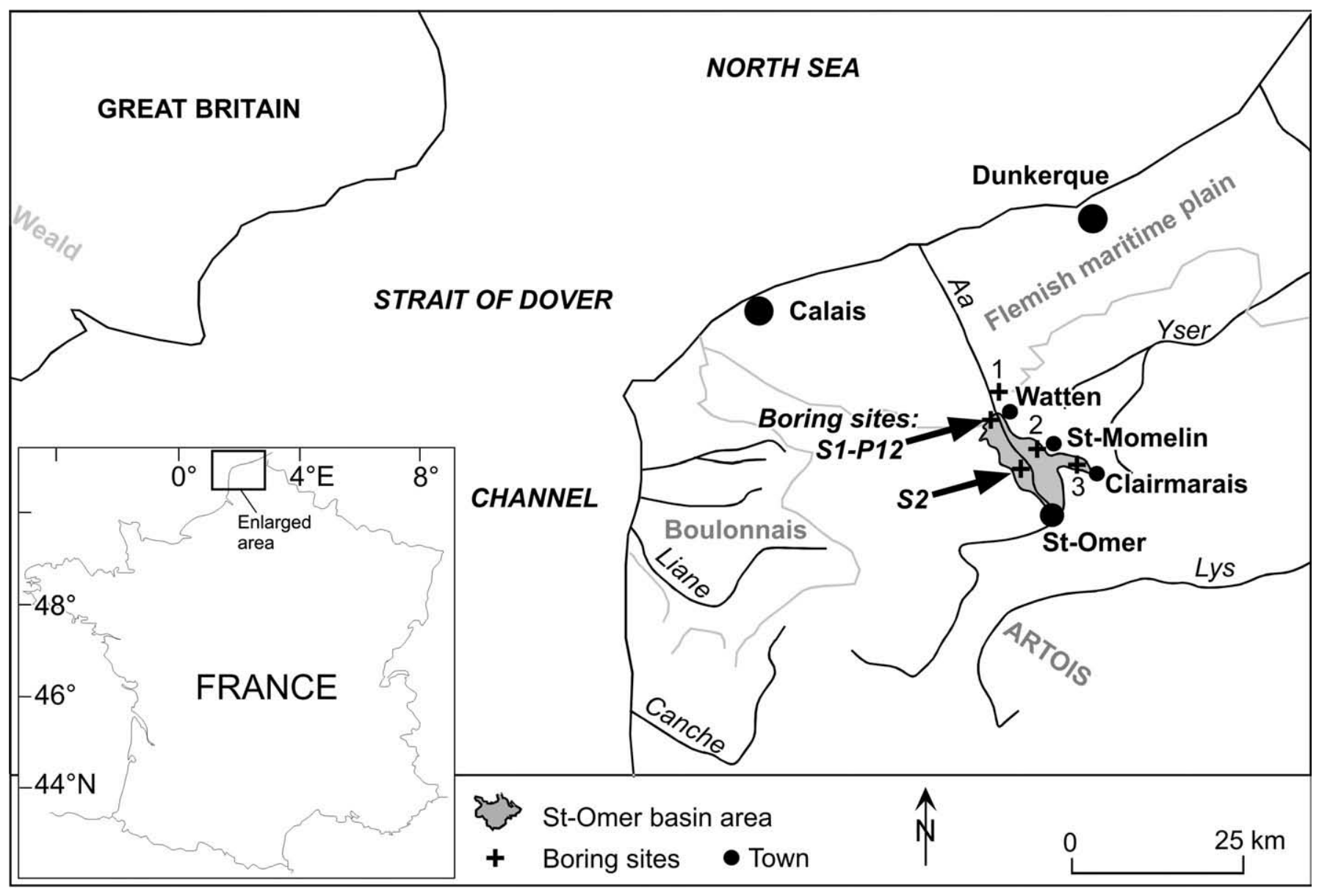

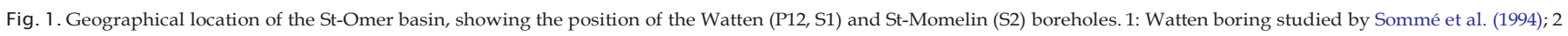
and 3: St-Momelin and Clairmarais borings studied by Van der Woude and Roeleveld (1985). 
WATTEN, P12: alt: $2 \mathrm{~m}$ a.s.I., Pas-de-Calais, France

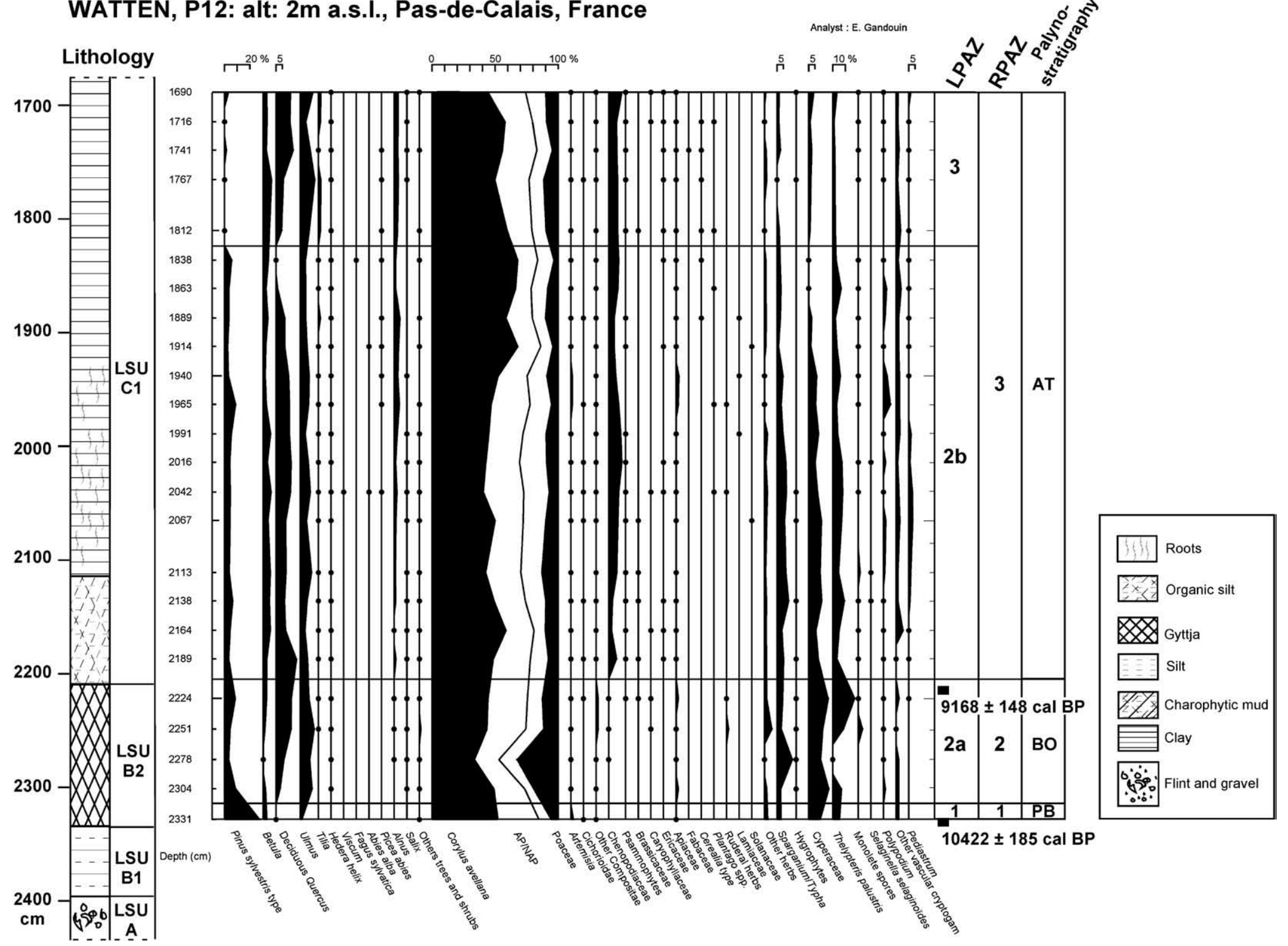




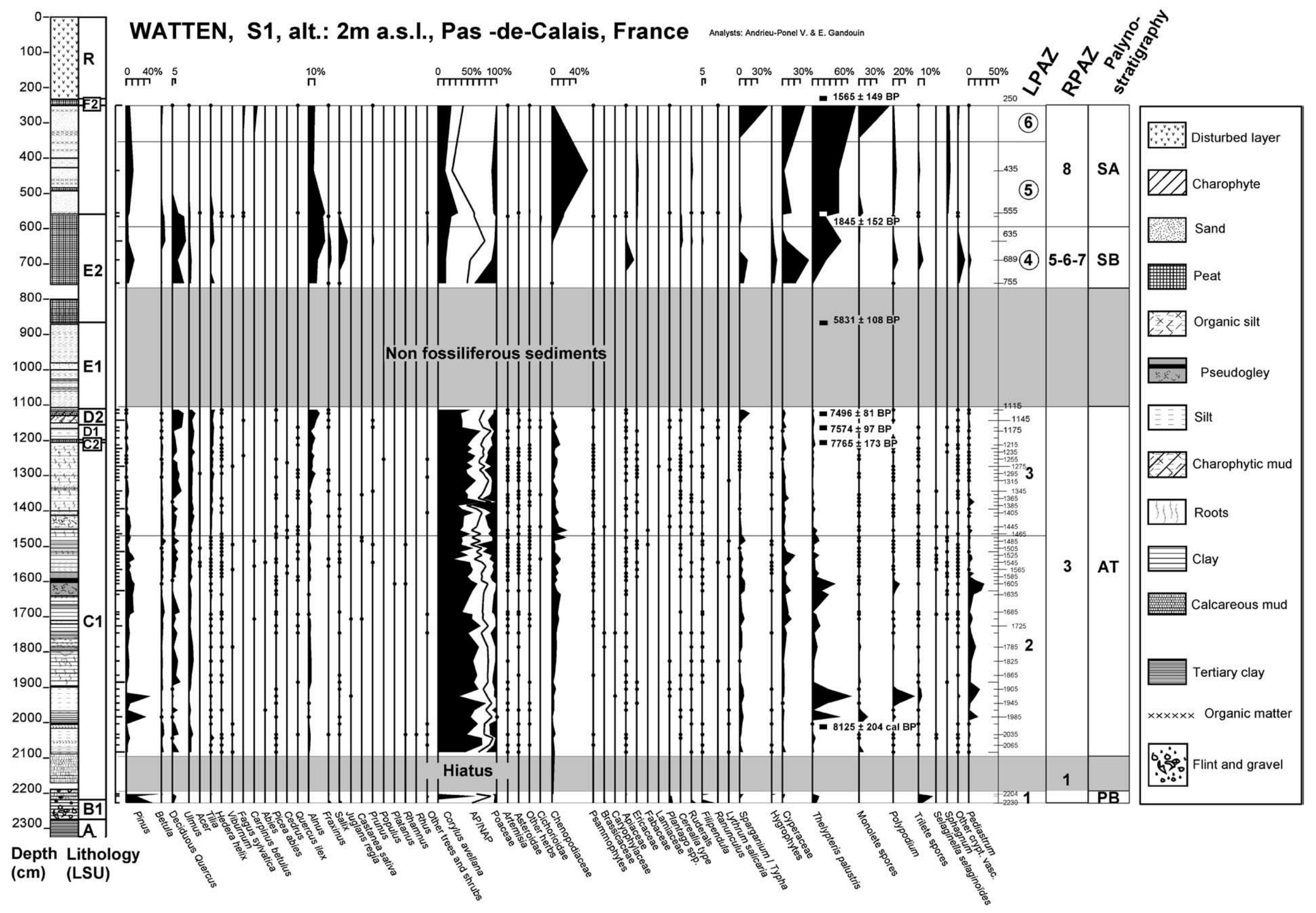

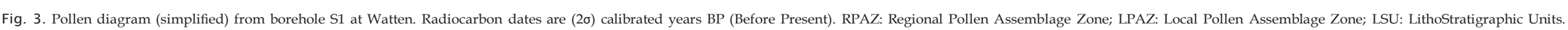

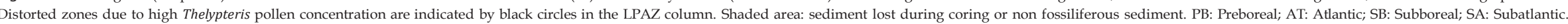


SAINT-MOMELIN, S2, alt.: $2 \mathrm{~m}$ a.s.I., Pas -de-Calais, France

Anaysts: E. Gandouin

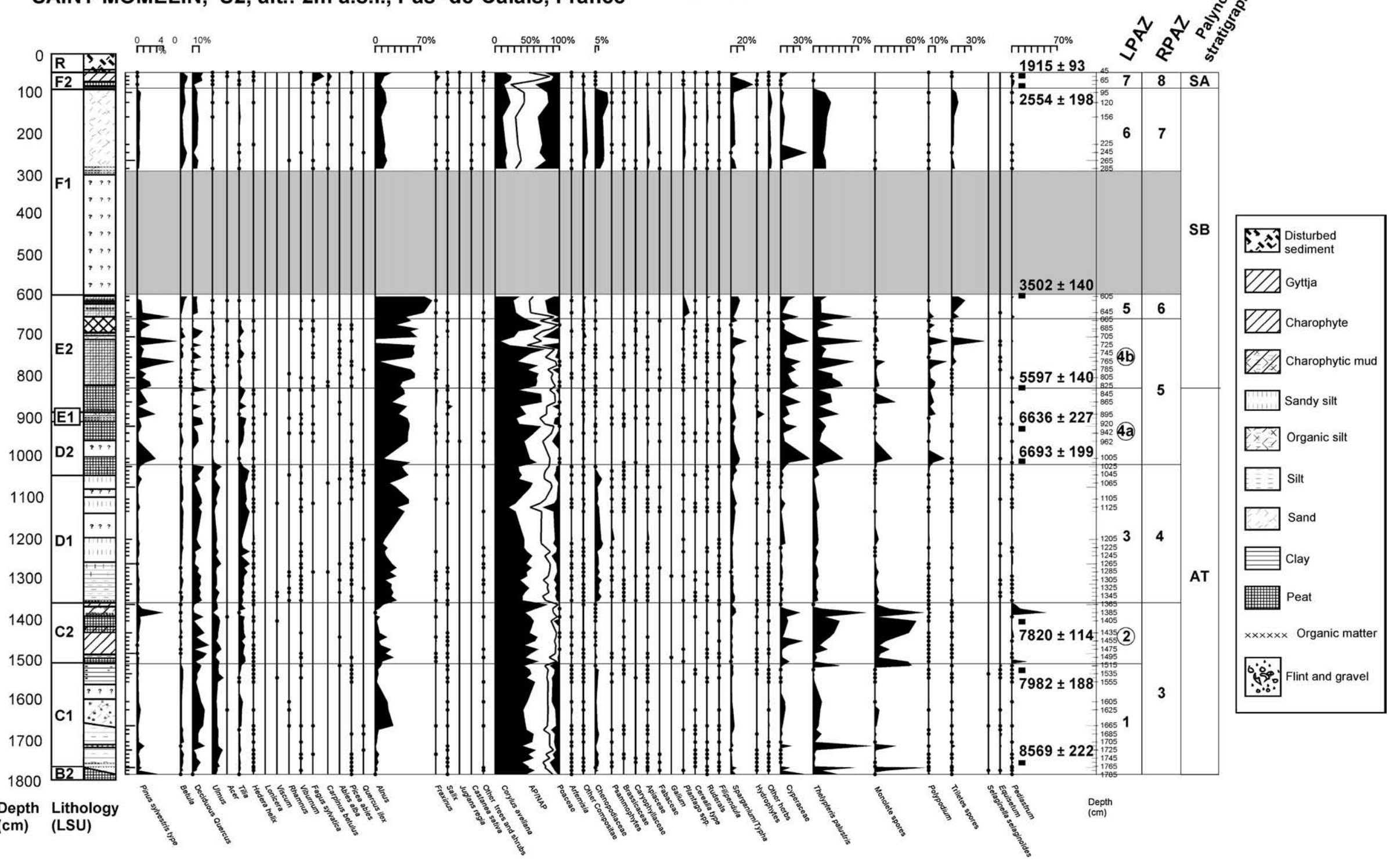

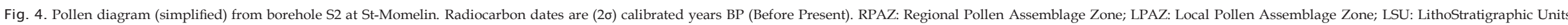
Distorted zones due to high Thelypteris pollen concentration are indicated by black circles in the LPAZ column. Shaded area: sediment lost during coring or non fossiliferous sediment. AT: Atlantic; SB: Subboreal; SA: Subatlantic. 


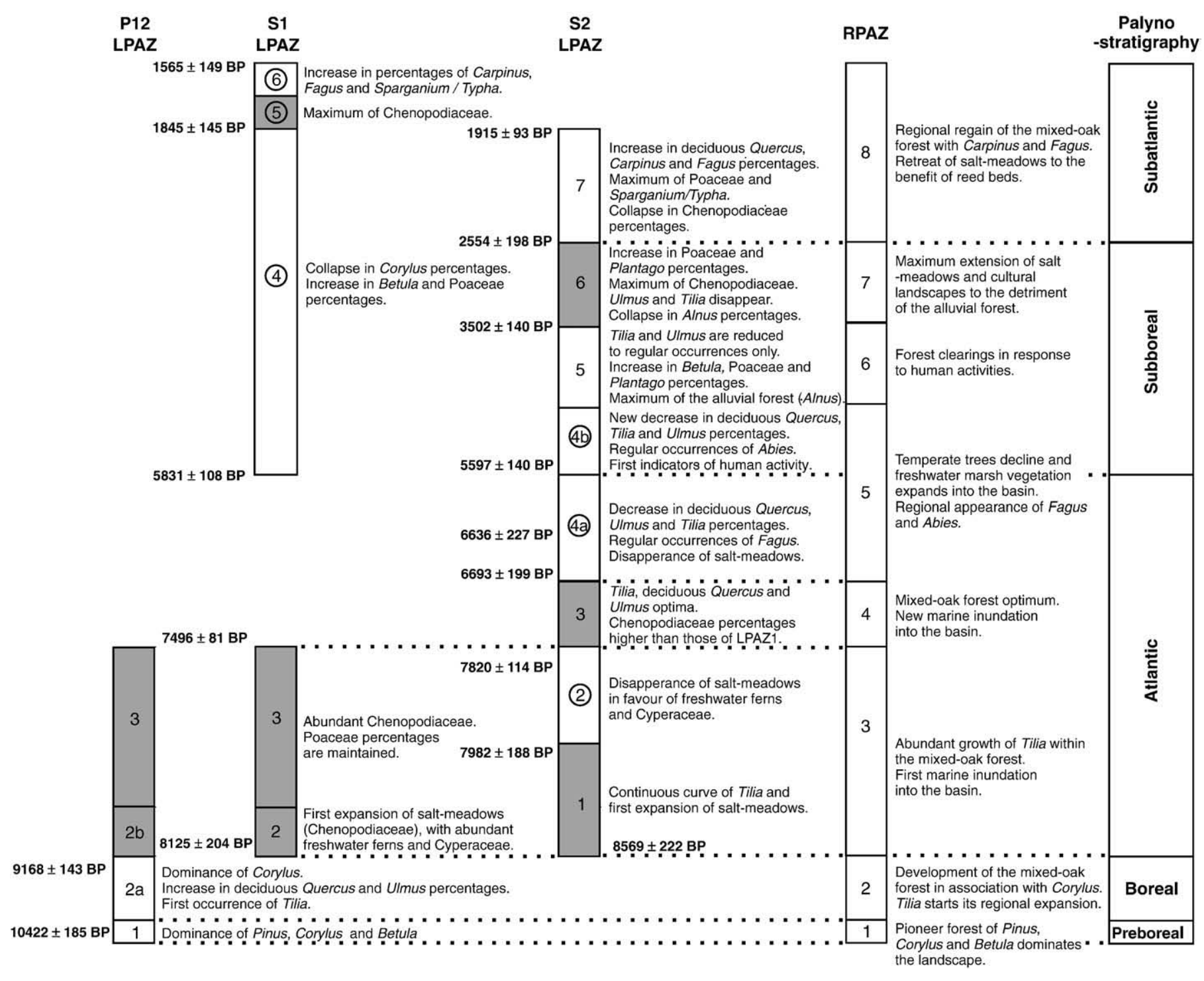

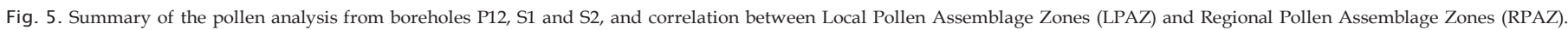

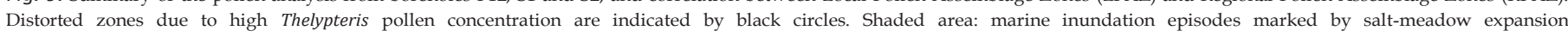

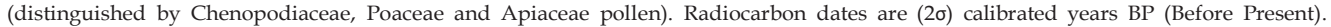

\subsection{Lithology and grain-size analysis}

Sedimentological data may provide additional information about environmental changes in the catchment area. Thus, continental and marine sediment from profiles P12, S1 and S2 were described in laboratory following the lithofacies descriptions of Allen (2003), Van der Woude and Roeleveld (1985), Sommé et al. (1994) and Berendsen and Stouthamer (2000). In order to provide information about past hydrodynamic processes (finer deposits may characterize standing water depositional environments whereas coarser deposits may correspond to running water environments), a total of 258 samples (each $1 \mathrm{~cm}$ thick) were taken throughout the three sedimentary profiles for grain-size analysis. This was performed with a laser particle analyser (MALVERN Mastersizer 2000 Ver. 5.00). Sediments were classified into three grain-size categories according to Chamley (2000): clay particles have a diameter of less than $2 \mu \mathrm{m}$; silt particles have a diameter comprised between 2 and $63 \mu \mathrm{m}$; and sand particles have a diameter greater than $63 \mu \mathrm{m}$. Clay from lithostratigraphical units A (LSU A) in profiles S1 and P12, and peat from LSU D2-E2 in profiles S1 and S2 were not analysed. A detailed grain-size analysis is given by Gandouin (2003).

\section{Results and palaeoenvironmental interpretations}

Based on sediment analyses, P12, S1 and S2 profiles were subdivided into twelve LSU (Table 2). Fig. 6 shows radiocarbon dates, RPAZ, LPAZ and LSU, and correlations between the P12, S1 and S2 profiles.

Occurrences (less than $1 \%$ of the pollen sum) of corroded pollen of Picea, Abies, Cedrus, Carpinus, and Pre-Quaternary palynomorphs were identified, these mainly occurred in minerogenic sediments of fluvial or estuarine origin. These should be attributed to sediment reworking during erosive phases (Waller, 1993). Thelypteris palustris is over-represented at Watten (S1) in pollen-poor sediments (S1: LAPZ 4 to 6) probably for taphonomic reasons. In profile S2, samples with a high content of Thelypteris and "monolete spores" are also rich in Pinus pollen. This has already been observed in other pollen records (Jalut et al., 1988; Reille and Andrieu, 1995) and may be interpreted as a distorted record due to pollen concentration induced by dense populations of Thelypteris. Pollen zones affected by this bias do not bear any ecological significance at a regional scale.

In northern Europe, the Chenopodiaceae family consists mainly of both halophilous and ruderal species. This mixture blurs the interpretation of 
Table 1

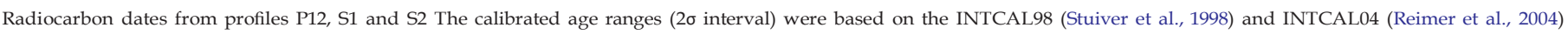

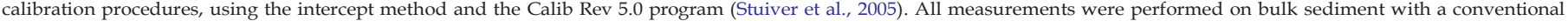
radiocarbon dating procedure. The radiocarbon dating was carried out by Beta Analytic (Miami) and the GAA-institut (Hannover).

\begin{tabular}{|c|c|c|c|c|c|c|c|c|}
\hline \multirow[t]{3}{*}{ Lab No. } & \multirow{3}{*}{$\begin{array}{l}\text { Depth } \\
(\mathrm{cm})\end{array}$} & \multirow{3}{*}{$\begin{array}{l}\delta{ }^{13} \mathrm{C} \% \\
\mathrm{PDB}\end{array}$} & \multirow[t]{3}{*}{ Samples } & \multirow{3}{*}{$\begin{array}{l}\text { Conventional } \\
\text { yrs BP }\end{array}$} & \multicolumn{4}{|l|}{ Datings } \\
\hline & & & & & \multirow{2}{*}{$\begin{array}{l}\text { Intcal98 } \\
\text { Cal. BP }\end{array}$} & \multirow[b]{2}{*}{ Cal. BC } & \multicolumn{2}{|l|}{ Intcal04 } \\
\hline & & & & & & & Cal. BP & Cal. BC \\
\hline S1: Beta-166495 & 241 & -30.1 & Organic sediment & $1680 \pm 60$ & $1570 \pm 150$ & $380 \pm 150$ Cal. AD & $1565 \pm 149$ & $1221 \pm 128$ \\
\hline S1: Beta-166494 & 558 & -28.8 & Peat & $1900 \pm 70$ & $1845 \pm 145$ & $145 \pm 105$ Cal. AD & $1845 \pm 152$ & $1450 \pm 157$ \\
\hline S2: Hv-24816 & $50-54$ & -29.3 & Peat & $1975 \pm 45$ & $1915 \pm 45$ & $75 \pm 25$ Cal. AD & $1915 \pm 93$ & $1533 \pm 130$ \\
\hline S2: Hv-24815 & $76-79$ & -31.9 & Peat & $2510 \pm 90$ & $2552 \pm 193$ & $615 \pm 200$ & $2554 \pm 198$ & $2140 \pm 218$ \\
\hline S2: Hv-24814 & $600-604$ & -29.7 & Peat & $3265 \pm 70$ & $3475 \pm 90$ & $1627 \pm 108$ & $3502 \pm 140$ & $3100 \pm 201$ \\
\hline S2: Beta-161064 & 830 & -29.0 & Peat & $4850 \pm 70$ & $5590 \pm 130$ & $3640 \pm 130$ & $5597 \pm 140$ & $5114 \pm 202$ \\
\hline S1: Beta-166493 & 860 & -28.4 & Peat & $5100 \pm 50$ & $5830 \pm 100$ & $3880 \pm 100$ & $5831 \pm 108$ & $5441 \pm 119$ \\
\hline S2: Beta-161063 & 935 & -30.0 & Peat & $5830 \pm 100$ & $6640 \pm 230$ & $4690 \pm 230$ & $6636 \pm 227$ & $6220 \pm 230$ \\
\hline S2: Hv-24813 & $1025-1030$ & -30.0 & Peat & $5880 \pm 80$ & $6737 \pm 103$ & $4850 \pm 80$ & $6693 \pm 199$ & $6300 \pm 176$ \\
\hline S1: Beta-166490 & $1126-1134$ & -26.3 & Peat & $6570 \pm 60$ & $7495 \pm 85$ & $5540 \pm 80$ & $7496 \pm 81$ & $7085 \pm 149$ \\
\hline S1: Beta-166491 & 1165 & -27.7 & Organic sediment & $6710 \pm 60$ & $7570 \pm 100$ & $5620 \pm 100$ & $7574 \pm 97$ & $7258 \pm 134$ \\
\hline S1: Beta-166492 & 1206 & -31.0 & Peat & $6920 \pm 100$ & $7765 \pm 185$ & $5820 \pm 180$ & $7765 \pm 173$ & $7420 \pm 176$ \\
\hline S2: Beta-161062 & 1400 & -28.5 & Peat & $6990 \pm 50$ & $7820 \pm 120$ & $5865 \pm 125$ & $7820 \pm 114$ & $7490 \pm 83$ \\
\hline S2: Hv-24812 & 1530 & -30.5 & Organic sediment & $7150 \pm 90$ & $7910 \pm 80$ & $6065 \pm 95$ & $7982 \pm 188$ & $7634 \pm 175$ \\
\hline S1: Hv-24811 & 2000-2015 & -26.2 & Organic sediment & $7250 \pm 110$ & $8022 \pm 103$ & $6080 \pm 100$ & $8125 \pm 204$ & $7727 \pm 206$ \\
\hline S2: Beta-161061 & 1723 & 28.3 & Peat & $7740 \pm 110$ & $8655 \pm 305$ & $6705 \pm 305$ & $8569 \pm 222$ & $8186 \pm 217$ \\
\hline P12: Beta-166498 & 2220 & -28.2 & Organic sediment & $8220 \pm 50$ & $9210 \pm 190$ & $7265 \pm 185$ & $9168 \pm 143$ & $8760 \pm 176$ \\
\hline P12: Beta-166499 & 2350 & -26.9 & Organic sediment & $9250 \pm 90$ & $10445 \pm 225$ & $8495 \pm 225$ & $10422 \pm 185$ & $9999 \pm 258$ \\
\hline
\end{tabular}

the signal that could be interpreted either as marine or anthropogenic. This problem is especially true over the last 5000 years. However, previous palaeoecological studies (Van der Woude and Roeleveld, 1985; Sommé et al., 1994) carried out on the St-Omer basin had already shown that Chenopodiaceae can be used as an efficient marine palynological signal, if associated to other markers like sedimentological and malacological evidences. In the present study, the malacofauna of the sediment contemporaneous with substantial percentages of Chenopodiaceae reveals the presence of molluscs such as Hydrobia ventrosa and $H$. ulvae. These species are characteristic of the middle reaches of estuaries with salt levels of $12-15 \%$ and of $20-30 \%$ respectively (Keen, unpublished data). Hence, in the littoral context of the St-Omer basin, Chenopodiaceae may be considered as signal of marine transgression. In addition, Ponel et al. (2007) showed that no extensive human activities occurred at St-Omer before $4180 \pm 45{ }^{14} \mathrm{C} \mathrm{BP}(4708 \pm 133 \mathrm{cal} \mathrm{BP})$.

\subsection{Tertiary and Pleistocene (LSU A and B1)}

LSU B1 (Figs. 2 and 3), overlaying the Tertiary clay from LSU A, consists of highly calcareous alluvial deposits characteristic of late Glacial cold periods (Antoine et al., 2000). Over much of NW Europe, where valleys cut through the chalk, calcareous muds were produced at this time by substrate gelifraction that accumulated in the valley bottoms (Ponel et al., 2005). At St-Omer, Ponel et al. (2007) ascribed LSU B1 to the Younger Dryas period based on cold adapted coleopteran assemblages and similarity with lithostatigraphic evi- dence from Britain (Coope, 1998), Belgium (Munaut and Paulissen, 1973) and the Netherlands (Berendsen and Stouthamer, 2000). The fine sandy silt deposits of this unit (silt $80 \%$, sand $15 \%$, clay $5 \%$ ) indicate a moderate flow of the river. Unfortunately the sediments from LSU B1 are devoid of pollen.

\subsection{The end of the Preboreal and the Boreal (LSU B2 and RPAZ 1-2)}

LSU B2 (Fig. 2) is situated above the Younger Dryas sediments and is characteristic of the peat infilling of a late Glacial palaeochannel from the English Channel and North Sea regions and may have been induced by a rise in the groundwater level in response to the progressive rise in sea level (Baeteman and De Gans, 1993; Berendsen and Stouthamer, 2000). This peat infilling began next to the river incision that took place at the transition between the Younger Dryas and the early Holocene (Starkel, 1991; Huisink, 2000; Antoine et al., 2003), in response to the dynamic adjustment of the river in wetter climatic conditions. The timing of this incision differs from one region to another. At St-Omer, the basal part of the peat from the P12 profile is dated to $10422 \pm 185 \mathrm{cal} \mathrm{BP}\left(9250 \pm 90{ }^{14} \mathrm{C} \mathrm{BP}\right)$. During this period, the St-Omer hydrographic system consisted of a river meandering through a vast marshy region, as observed in most of the alluvial plains from northern France (Antoine et al., 2000).

Pollen data from the St-Omer basin show that during the Preboreal, pioneer forests of Pinus, Corylus and Betula dominated the landscape, as observed in the Somme basin (Antoine et al., 2000), the

Table 2

Lithostratigraphical units (LSU).

\begin{tabular}{|c|c|c|}
\hline Lithofacies & Descriptions & Depositional environments \\
\hline LSUR & Sediment disturbed by agricultural activities & \\
\hline LSU F2 & Blackish-brown peat and charophyte-mud & Freshwater swamp or salt marsh \\
\hline LSU F1 & Sand & Tidal channel (higher hydrodynamism) \\
\hline LSU E2 & Blackish-brown peat and organic rich muds, associated with plant debris and laminated with fine sand layers & Freshwater swamp or salt marsh \\
\hline LSU E1 & Silty sands & Tidal channel \\
\hline LSU D2 & Blackish-brown peat and charophyte-mud & Freshwater swamp or salt marsh \\
\hline LSU D1 & Sandy silts & Tidalchannel \\
\hline LSU C2 & Blackish-brown peat, charophyte or organic muds associated with plant debris & Freshwater swamp or salt marsh \\
\hline LSU C1 & Clayey silts millimetric laminated and occasionally bioturbated by roots and shells & Intertidal mudflats \\
\hline LSU B2 & Blackish-brown peat associated with plant debris (leaves, twigs and tree trunks) & Freshwater swamp (infilling side-arm or oxbow lake) \\
\hline LSU B1 & Calcareous alluvial sandy silts with pebbles and flints & Braided river channel \\
\hline LSU A & Light grey tertiary clay & - \\
\hline
\end{tabular}




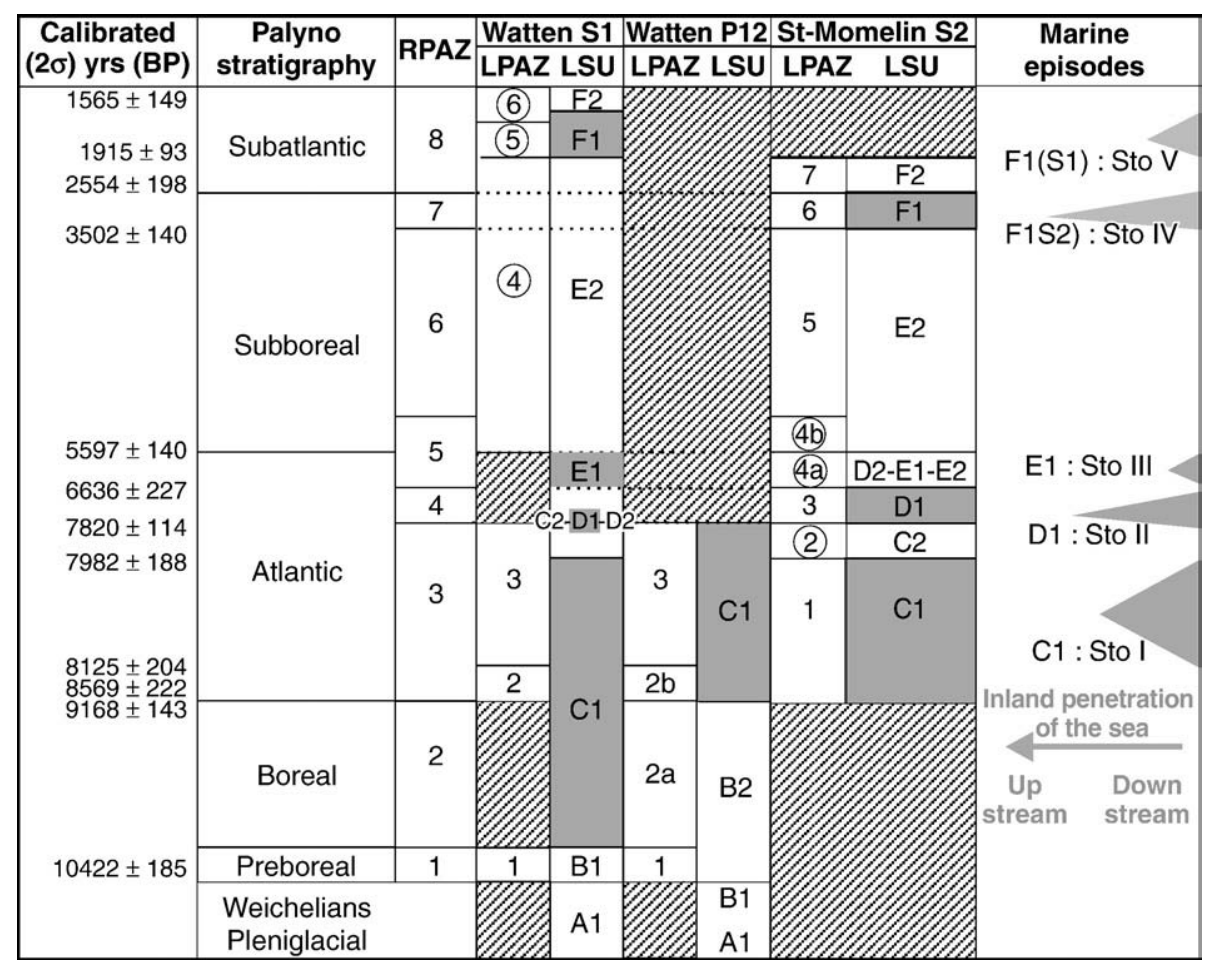

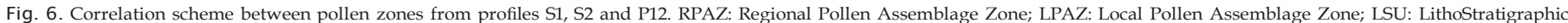

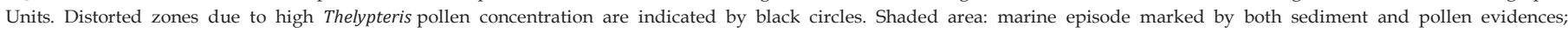

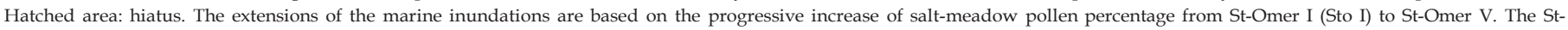
Omer III and V are only recorded downstream of the basin in profile S1.

Paris basin (Van Zeist and Van der Spoel-Walvius, 1980; Bakels, 1995; Pastre et al., 2000), the Scarpe Valley (Munaut et al., 1995). Percentages of "deciduous Quercus" increased during the Boreal but this taxon was already present at the end of the Preboreal (RPAZ 1). The abundance of Corylus (more than $50 \%$ of the pollen sum) in association with the mixed-oak forest (deciduous Quercus, Ulmus, and Hedera) and the first occurrences of Tilia mark the Boreal chronozone (Sommé et al., 1994).

\subsection{The beginning of the Atlantic ( $L S U C 1, C 2, D 1$, and RPAZ 3-4)}

The laminated clayey silts of LSU C1 (silt $80 \%$, sand 15\%, clay 5\%) can accumulate in a wide range of depositional conditions, including subtidal, tidal and minerogenic saltmarsh environments. However, the presence of halophilous herb pollen such as Chenopodiaceae (LPAZ-2 in S1 - Fig. 3 and LPAZ-2b in P12 - Fig. 2) indicates salt water input into the basin and progressive increase in regional marine influence, at the onset of the Calais transgression. High values in clay and silt particles into downstream profiles (P12 and S1), characteristic of low hydrodynamism, as well as abundances of Cyperaceae and freshwater ferns such as Thelypteris palustris (LPAZ 2 (S1) and LPAZ 2b (P12)) indicate that the marine influence was low and that the sea was probably still far away from the basin.

The salt-meadow expansion that occurred in the coastal plain downstream of Watten (Sommé et al., 1994) induced the opening of the landscape and favoured the establishment of Betula, as recorded in P14 and P12 assemblages. At that time, the mixed-oak forest probably grew on drained slopes of the watershed. Tilia appeared locally in the mixed-oak forest just before $7982 \pm 188 \mathrm{cal} B P\left(7150 \pm 90{ }^{14} \mathrm{C}\right.$ BP; S2 profile)and expanded toits maximum(RPAZ4) around 6693 $\pm 199 \mathrm{cal}$ $\mathrm{BP}(5880 \pm 80 \mathrm{BP})$; this is in agreement with the date of $5690 \pm 80{ }^{14} \mathrm{C}$ $(6483 \pm 171 \mathrm{cal} \mathrm{BP})$ at Watten (Sommé et al., 1994), with the date of $5300 \pm 70{ }^{14} \mathrm{C}(6071 \pm 144 \mathrm{cal} \mathrm{BP})$ at Bazoches in Vesle valleys (Bakels, 1995) and other pollen data from Great Britain (Jones and Keen, 1993).
The peaty and organic sediments of LSU C2 (Fig. 4) above the marine deposits of LSU C1 correspond to the organic infilling of a palaeochannel. This short event could have occurred during a pause, or a slight regression, in the sea level rise in response to glacio-hydroeustatic readjustments, sediment compaction and neotectonic processes (Denys and Baeteman, 1995; Lambeck, 1997; Waller and Long, 2003). At that time, a Cyperaceae marsh with abundant freshwater plants such as Thelypteris palustris dominated the vegetation basin upstream.

The coarser LSU D1 deposits in profile S2 (sand 50\%, silt 50\%, clayb1\%) associated with higher percentages of Chenopodiaceae denote an increase of marine influence throughout the basin, with higher hydrodynamism. The basin was flooded by the sea, allowing salt-marshes and salt-meadows to extend (RPAZ 4). This marine inundation occurred between $7820 \pm 114$ and $6693 \pm 199 \mathrm{cal} \mathrm{BP}$ $\left(6990 \pm 50\right.$ and $\left.5880 \pm 80{ }^{14} \mathrm{CBP}\right)$.

\subsection{The end of the Atlantic (LSU D2, E1 and RPAZ 5 basis: LPAZ 4a (S2))}

At the end of the Atlantic period, a vast marshy area occupied the basin and favoured the deposition of peat (LSU D2-E2/Fig. 4) within the river and tidal paleaochannels. Such an event is often observed along the marine plains of the North Sea and the English Channel (Sommé et al., 1994; Berendsen and Stouthamer, 2000). The StMomelin sequence provides a detailed record of vegetation dynamics that corresponds to the end of the mid-Holocene climate optimum (circa $6700 \mathrm{cal} \mathrm{BP} / 5880{ }^{14} \mathrm{C} \mathrm{BP}$, at the base of LPAZ 4a). This moderate deterioration of the climate led to a decline of temperate trees (Ulmus, Tilia, deciduous Quercus) and to the first occurrences of Fagus pollen (in LPAZ 4a). As thermal requirements of Fagus are less constraining than those of other temperate trees, this cooler period did not prevent it from continuing its regional extension. The extension of Fagus to the detriment of other trees could also be attributed to the effect of light competition, since Fagus grows easily below a dense canopy. 
At St-Momelin (Fig. 4), the decrease in marine influence is shown by a decline in the percentage of halophilous pollen- for example Chenopodiaceae values fall to less than $1 \%$ of the pollen sum- and high values of freshwater and hygrophilous plants. At Watten (Fig. 3), it seems that the marine influence persisted, as suggested by the high energy of the deposit (LSU E1: sand $60 \%$, silt $40 \%$, clay b $1 \%$ ). Unfortunately, the absence of pollen in the sediment, probably for taphonomic reasons, cannot strengthen this interpretation.

\subsection{The Subboreal (LSU E2, F1, RPAZ 5 top to RPAZ 7)}

The Subboreal is characterized by the disappearance of the marine influence all over the St-Omer basin, as suggested by thick peaty deposits (LSU E2), abundance of freshwater fern spores in profiles S1 and S2 (Figs. 3 and 4), and the forest development on the alluvial plain which is dominated by Alnus (pollen percentages of Alnus exceed 50\% of the pollen sum on average, reaching more than $70 \%$ in LPAZ5 in profile S2).

The climatic cooling that began at the end of the Atlantic is still recorded during the Subboreal, as suggested by the appearance of regular occurrences of Abies, and a decrease in Tilia (LPAZ4b, profile S2). This event, along with the decline of Ulmus recorded in LPAZ 4a and b (Fig. 4), occurs after $5597 \pm 140$ cal BP $\left(4850 \pm 70{ }^{14} \mathrm{C} \mathrm{BP}\right)$. In Europe the elm decline is dated to the end of the Atlantic and to the Subboreal, and should probably be attributed to several factors such as disease, human impact (Peglar, 1993) and interspecific competition, especially with Fagus (Van der Woude and Roeleveld, 1985; Sommé et al., 1994).

The first indicators of human activity are also recorded during the Subboreal (decrease in arboreal pollen and high percentages of Plantago in LPAZ 5 of S2 profile, Fig. 4). In LPAZ 6 (S2), Alnus percentages collapse (70\% in LPAZ 5 (S2) to 10\% in LPAZ 6 (S2)). The strong increase of Chenopodiaceae suggests that the retraction of the Alnus forest was to the benefit of halophytic vegetation and should be attributed to a rise in brackish groundwater. This vegetation change could be related to a marine transgression episode dated to circa $2554 \pm 198 \mathrm{cal} \mathrm{BP/}$ $2510 \pm 90{ }^{14} \mathrm{C}$ BP (top of LPAZ 6, profileS2), and correlates with the known marine transgression of Dunkerque. During this marine episode the coarse sediments of LSU F1 (85\% of sand) suggest an important hydrodynamism.

Sustained percentages of Plantago in LPAZ 6 (S2) show that the decline in the forest cover (arboreal pollen below $40 \%$ of the total pollen sum) was likely to have been of human origin, and was probably associated with the expansion of grazed grasslands.

\subsection{The Subatlantic (LSU F1, F2 and RPAZ 8)}

The regional vegetation is clearly recorded in profileS2 only (Fig. 4), as profile S1 is dominated by freshwater ferns (such as Thelypteris) introducing distortion in the pollen assemblage (see the onset of the $\S 4)$. At St-Momelin, as well as in Subatlantic pollen sequences from northern France and Belgium (Munaut, 1967; Heyvaert, 1980), Fagus and Carpinus grew within groves of deciduous Quercus in areas not strongly disturbed by agro-pastoral activities.

The marine influence fluctuated throughout the Subatlantic. A continental period dated from $2554 \pm 198$ to $1915 \pm 93 \mathrm{cal} \mathrm{BP} / 2510$ to $1975^{14 \mathrm{C}} \mathrm{BP}$ (LSU F2) is recorded in profile S2. In LPAZ 7, the pollen data illustrate that this peaty sedimentation was contemporaneous with a freshwater marsh densely inhabited by hygrophytic and hydrophytic plants (e.g., Sparganium/Typha, Rumex aquaticus and Nymphaea alba). A marine episode is recorded in profile S1 (LSU F1) between 1845 \pm 152 and $1565 \pm 149$ cal BP $\left(1900 \pm 70\right.$ and $\left.1680 \pm 60{ }^{14} \mathrm{C} \mathrm{BP}\right)$ at Watten. This episode is contemporaneous with a strong increase in Chenopodiaceae percentages (LPAZ 5, profile S1) and a high hydrodynamism of palaeochannels (sand percentage close to $90 \%$ ). At the top of profile S1 (LPAZ 6, Fig. 3), the decrease in marine influence is marked by a fall in Chenopodiaceae percentages associated with an increase in freshwater ferns (Thelypteris palustris). This probable sea retreat favoured the peat deposition observed in LSU F2 (profile S1).

\section{Discussion}

Lithology and pollen data show that the St-Omer basin was strongly subjected to marine influence at several periods of the Holocene. For each marine episode, the sediment is always characterized by a pollen content dominated by high percentages of halophilous taxa (especially Chenopodiaceae). Such change in the vegetation indicates that salt-meadows became established nearby (Morzadec-Kerfourn, 1974; Heyvaert, 1980), maybe induced by a transgressive marine pulse (Metcalfe et al., 2000; Shennan et al., 2000).

At St-Omer, Chenopodiaceae values are increasingly represented in the pollen spectra of the successive estuarine deposits. This could suggest that marine pulses were gradually more extensive. Sedimentological data are also in agreement with this progressive increase in marine influence, because of a change in the sedimentation from a dominant silty regime to a dominant sandy regime, as seen in consecutive palaeochannel complexes (C1, D1, E1 and F1) of P12, S1 and S2 profiles (Figs. 2-4). This has been confirmed by Gandouin (2003) and Gandouin et al. (2007b) in a sedimentological synthesis of 22 boreholes throughout the basin. Nevertheless, as mentioned above, Chenopodiaceae are also ruderal plants often associated to agricultural activities. Hence, this signal must be taken with care in the younger part of the sequence (Neolithic period) because Chenopodiaceae could be overestimated with the cumulative effect of both anthropogenic and marine factors. Moreover, coleopteran data from Ponel et al. (2007) do not contain any taxa associated with cultivated fields until $4708 \pm$ 133 cal BP $\left(4180 \pm 45{ }^{14} \mathrm{C} \mathrm{BP}\right)$; on the contrary several beetle species typical of pristine, undisturbed primeval forests were identified, for example Mycetina cruciata, Dromaeolus barnabita and Dirrhagus lepidus. The occurrence of Mycetina cruciata is especially significant since this saproxylophagous beetle is associated with old forests not affected by human action ("urwald" forests), where it is found in wet rotten wood attacked by fungi. Pollen data are in agreement with this interpretation because of the increase of classical anthopogenic indicator plants, such as cereals and Plantago, after ca $4000{ }^{14} \mathrm{C}$ BP only (Fig. 4: LPAZ5 in S2 profile). After this date, evidence for human impact can be seen in the sudden decrease in the Arboreal/Non Arboreal Pollen curve (AP/NAP ratio), characteristic of major forest clearance.

Sea retreat phases induced the contraction of the estuary and the infilling of the basin with freshwater from the water table, the river Aa and its tributaries; this enabled peat to be deposited in the palaeochannels (Berendsen and Stouthamer, 2000). Thus, fresh water conditions prevailed and favoured the predominance of alluvial forests and swamps (dominated by Alnus, Thelypteris, and Cyperaceae). The mixed-oak forest was restricted to drained slopes and hills bordering the Aa river catchment, as observed by Van der Woude and Roeleveld (1985) at Clairmarais and St-Momelin. The successive variations in the extent of marine conditions have also an indirect impact on estuarine and floodplain vegetation; this is due to the fact that marine pulses undoubtedly disturbed the vegetation dynamics throughout the Holocene by maintaining a semi-open landscape, with a recurrent grow of pioneering taxa such as Betula and Corylus.

At St-Omer, as observed by Van der Woude and Roeleveld (1985) and Sommé et al. (1994) it is assumed that the Holocene sea level rises led to the deposit of two main marine sedimentary layers attributed to the Calais and Dunkerque transgressions. These layers are intercalated within the late Atlantic/Subboreal peat. However this marine transgressive scheme has now been dropped by most of the research groups working on the North Sea coasts (e.g., Behre et al., 2004), because it perpetuates an unjustified assumption according which all the coastal 
areas along the southern North Sea responded in the same way and at the same time. Thus, the present study allowed the description of several subdivisions within the Calais-Dunkerque scheme and the development of an independent and locally-based scheme where: Calais marine sediments were deposited during the salt water input episodes of StOmer I, II and III; and Dunkerque marine sediments were deposited during the salt water input of St-Omer IV and V.

At the beginning of the flandrian transgression, during St-Omer I, the marine influence was weak as suggested by both low hydrodynamism (presence of laminated clay-silty sediments) and low percentages of halophilous taxa (Fig. 4.), maybe localised downstream of the basin and washed-up from more littoral areas during storm events. The beginning of St-Omer I is dated to $9168 \pm 143 \mathrm{cal}$ BP at Watten (-20 m N.G.F., "Nivellement Général de la France") and to $8569 \pm 222$ cal BPatSt-Momelin ( $-14 \mathrm{~m}$ N.G.F.). This is in agreement with Sommé et al. (1994) who date the beginning of the flandrian transgression on the maritime plain of Watten to the onset of the Boreal (-21.5 m N.G.F.).

On the coast of Picardie between Berck and Merlimont $(-21 \mathrm{~m}$ N.G.F.), the onset of the flandrian transgression is dated to circa 7400 ${ }^{14} \mathrm{C}$ BP (Vinchon et al., 2000), around $8200 \mathrm{cal}$ BP with the Intcal04 data set (Reimer et al., 2004). The difference in the timing of the transgression at Watten (P12 profile) and on the coast of Picardie could be explained by two hypotheses that are not mutually exclusive. First, an early incision of the Aa channel, during the Pleniglacial and at the late Glacial/Holocene transition, as in most European river systems (Huisink, 2000; Ménot et al., 2006), would have facilitated the marine inundation of the basin. A second hypothesis is a penetration of the sea from the North Sea, contrary to the classic transgression outline given by Jelgersma (1979) who assumed that the Calais transgression reached the present coast of Zeeland $(-17 \mathrm{~m})$ through the Lobourg palaeovalley $(-50 \mathrm{~m})$ at around $8300{ }^{14} \mathrm{C}$ BP (Jelgersma, 1979), $9300 \mathrm{cal}$ BP with the Intcal04

data set (Reimer et al., 2004). This also could have been induced by strong subsidence in the St-Omer basin area (Mansy et al., 2003).

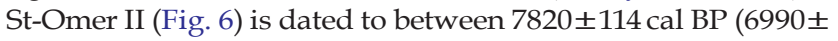
$\left.50{ }^{14} \mathrm{C} \mathrm{BP}\right)$ and $7496 \pm 81 \mathrm{cal} \mathrm{BP}\left(6570 \pm 80{ }^{14} \mathrm{C} \mathrm{BP}\right)$. This is a transgressive phase which followed a short phase of stability (documented by a peaty layer dated to $7982 \pm 188 \mathrm{cal}$ BP $(7150 \pm 90$ $\left.{ }^{14} \mathrm{C} \mathrm{BP}\right)-7820 \pm 114 \mathrm{cal} \mathrm{BP}\left(6990 \pm 50{ }^{14} \mathrm{C} \mathrm{BP}\right)$; see LSU C2 on S2 profile). The sea penetrated landward beyond the maximal extension

previously reached during the St-Omer I episode, and subsequently induced an expansion of halophilous grasslands.

At Watten, St-Omer III is dated prior to $5831 \pm 108 \mathrm{cal}$ BP $(5100 \pm$ $50{ }^{14} \mathrm{C} \mathrm{BP}$, Fig. 3). The age of this low amplitude event is close to the estimate of $5100-4400{ }^{14} \mathrm{C}$ BP attributed by Behre (2004) to Calais III in Lower Saxony (northern Germany). In northern France this episode has never been identified as a transgression sensu strictu (Van VlietLanoë et al., 2004) and it is probably generated by stormy events (Meurisse-Fort, 2008). This could explain the absence of halophilous vegetation in pollen assemblages from St-Momelin at that time.

At the Atlantic/Subboreal transition the Calais deposits are overlain by peats which can be correlated with organic layers observed in the coastal plains along the North Sea (Sommé, 1977; Van der Woude and Roeleveld, 1985; Waller, 1994). Peat was deposited landward of the coastal sand barriers, in swampy areas, during periods marked by a decrease or a pause in the rate of sea level rise (Berendsen and Stouthamer, 2000). Subsequently, the Subboreal peats were eroded at St-Momelin before $2554 \pm 198$ cal BP $\left(2510 \pm 90{ }^{14} \mathrm{C} \mathrm{BP}\right)$ during the StOmer IV transgressive episode. This episode could correspond with the regional Dunkerque I, poorly documented in the regional marine sequences (Sommé, 1977; Van Vliet-Lanoë et al., 2004). However, high values of Chenopodiaceae (Fig. 4.) confirm that the St-Omer basin was subjected to marine influence at that time.

At a regional scale, Dunkerque II is assumed to be the main marine inundation (Sommé et al., 1994). Surprisingly, it seems to be only recorded at Watten (Figs. 3 and 6), within the St-Omer basin, during the St-Omer V inundation. As for St-Omer III, this low amplitude event could therefore be explained by a marine inundation following a strong storm event, as suggested also by Meurisse et al. (2005) from the study of littoral sequences from Picardie.

\section{Conclusion}

(i) The Holocene vegetation of the St-Omer basin has mainly been shaped by an alternation of estuarine and fluvial processes, inducing successive phases of expansion or retraction of salt-meadows, freshwater marshy vegetation and alluvial alder forest. However, regional vegetation dynamics are also recorded in the St-Omer pollen sequence. Comparison with other continental sequences from northern France, Belgium and south-eastern Britain shows that the climatic trends described during the Holocene, such as the early Holocene climate improvement or the late Atlantic cooling, have also been recorded elsewhere, and suggests that the St-Omer pollen sequence contains a reliable record of Holocene climate changes. This point will allow a further comparison with Chironomids (Gandouin et al., 2007a) and Coleopteran (Ponel et al., 2007) data that have clearly shown an important role of the climate on Holocene faunal assemblage succession from St-Omer. Hence, it will be possible to infer a regional climatic signal from biological assemblages in a region for which climatic data are rare, due to the lack of lacustrine records unaffected by flooding.

(ii) The cross-comparison of sediment, pollen and radiocarbon data analyses allowed us to evidence the five main marine inundations that affected theSt-Omer basin.St-Omer I, which started earlier at Watten in the lower part of the basin, is dated to $9168 \pm 143 \mathrm{cal} \mathrm{BP}$

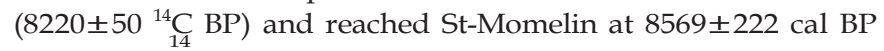
$(7740 \pm 110$ C BP). St-Omer II is dated to between $7820 \pm 114 \mathrm{cal} \mathrm{BP}$ $\left(6990 \pm 50{ }^{14} \mathrm{C} \mathrm{BP}\right)$ and $7496 \pm 81 \mathrm{cal} \mathrm{BP}\left(6570 \pm 60{ }^{14} \mathrm{C} \mathrm{BP}\right)$ and penetrated landward into the basin. St-Omer III is only observed at Watten, prior to $5831 \pm 108$ cal BP $\left(5100 \pm 50{ }^{14} \mathrm{C} \mathrm{BP}\right)$. This low amplitude marine inundation was probably generated by a storm event. St-Omer IV reached St-Momelin in the upper part of the basin and is dated to between $3502+\frac{1}{14} 140 \mathrm{cal} B P\left(3265 \pm 70{ }^{14} \mathrm{C} \mathrm{BP}\right)$ and $2554 \pm 198$ cal BP $(2510 \pm 90$ C BP $)$. On the cpntrary, St-Omer V (dated to between $1845 \pm 152 \mathrm{cal} \mathrm{BP}(1900 \pm 70 \quad \mathrm{C} \mathrm{BP})$ and $1565 \pm$ $\left.149 \mathrm{cal} \mathrm{BP}\left(1680 \pm 60{ }^{14} \mathrm{C} \mathrm{BP}\right)\right)$ is recorded only at Watten and may result from a storm event.

(iii) Pollen data confirm that human populations were installed close to the St-Omer basin during the Subboreal, their activity induced a strong opening of the landscape and massive deforestation. The impact of human activities on the environment began from about $4500 \mathrm{cal} \mathrm{BP}$ and increase until ca $2500 \mathrm{cal}$ BP. After this date, pollen data have shown a return of woodlands, probably in response to a decrease in human pressure in the area and/or to a change in land use.

\section{Acknowledgements}

This study was funded by ANDRA (Agence Nationale pour la gestion des Déchets Radio Actifs). The BRGM (Bureau de Recherches Géologiques et Minières) provided logistic support for boring. Thanks are due to Alain Trentesaux, Deny Malengros, Philippe Recourt, Daniel Dupuis and Jean-François Lauzach for help during field work and in the laboratory. Suzi Richer helped with the English translation.

\section{References}

Allen, J.R.L., 2003. An eclectic morphostratigraphic model for the sedimentary response to Holocene sea-level rise in northwest Europe. Sedimentary Geology 161, 31-54 Angulo, R.J., Giannini, P.C.F., Suguio, K., Pessenda, L.C.R., 1999. Relative sea-level changes in the last 5500 years in southern Brazil (Laguna-Imbituba region, Santa Catarina State) based on vermetid 14C ages. Marine Geology 159, 323-339. 
Antoine, P., Lautridou, J.P., Laurent, M., 2000. Long-term fluvial archives in NW France: response of the Seine and Somme rivers to tectonic movements, climatic variation and sea-level changes. Geomorphology 33, 183-207.

Antoine, P., Munaut, A.-V., Limondin-Lozouet, N., Ponel, P., Dupéron, J., Dupéron, M., 2003. Response of the Selle River to climatic modifications during the Lateglacial and Early Holocene (Somme Basin-Northern France). Quaternary Science Reviews 22, 2061-2076

Baeteman, C., De Gans, W., 1993. International union for quaternary research subcommission on shorelines in Europe. Fieldmeeting 1993: Quaternary shorelines in Belgium and the Netherlands. Belgian Geological Survey-Geological Survey of the Netherlands-Earth Technology Institute.

Bakels, C., 1995. Late Glacial and Holocene pollen records from the Aisne and Vesle valleys, Northern France: the pollen diagrams Maizy-Cuiry and Bazoches. Mededelingen Rijks Geologische Dienst 52, 221-234.

Behre, K.E., 2004. Coastal development, sea-level change and settlement history during the later Holocene in the Clay District of Lower Saxony (Niedersachsen), northern Germany. Quaternary International 112, 37-53.

Berendsen, H.J.A., Stouthamer, E., 2000. Late Weichselian and Holocene palaeogeography of the Rhine-Meuse delta, The Netherlands. Palaeogeography, Palaeoclimatology, Palaeoecology 161, 311-335.

Bohncke, S.J.P., Vandenberghe, J., 1991. Palaeohydrological development in the Southern Netherlands During the last 15000 years. In: Starkel, L., Gregory, K.J., Thornes, J.B. (Eds.), Temperate Palaeohydrology. John Wiley and Sons Ltd, Chichester, pp. 254-281.

Chamley, H., 2000. Base de sédimentologie. Dunod, Paris

Coope, G.R., 1998. Part V. The biostratigraphy and palaeoecology. 4. Insects. In: Preece, R.C. Bridgland, D.R. (Eds.), Late Quaternary Environmental Change in North-west Europe: Excavations at Holywell Coombe, South-east England. Chapman \& Hall, London, pp. 213-232.

Denys, L., Baeteman, C., 1995. Holocene evolution of relative sea level and local mean high water spring tides in Belgium - a first assessment. Marine Geology 124,1-19.

Dubois, G., 1924. Recherches sur les terrains quaternaires du nord de la France. Mémoire de la Société Géologique du Nord.

Faegri, K., Iversen, F., Kaland, P.E., Krzywinski, K., 1989. Textbook of Pollen Analysis, fourth edition. John Wiley, Chichester.

Freund, H., Gerdes, G., Streif, H., Dellwig, O., Watermann, F., 2004. The indicative meaning of diatoms, pollen and botanical macro fossils for the reconstruction of palaeoenvironments and sea-level fluctuations along the coast of Lower Saxony; Germany. Quaternary International 112, 71-87.

Gandouin, E., 2003. Enregistrement paléoclimatique interdisciplinaire de la transgression holocène. Signature paléoenvironnementale des Chironomidae (Diptères) du bassin de St-Omer (France). ANDRA, Paris.

Gandouin, E., Franquet, E., Van Vliet-Lanoë, B., 2005. Chironomids (Diptera) in river floodplains: their status and potential use for palaeoenvironmental reconstruction purposes. Archiv für Hydrobiologie 162, 511-534.

Gandouin, E., Maasri, A., Van Vliet-Lanoë, B., Franquet, E., 2006. Chironomid (Insecta: Diptera) assemblages from a gradient of lotic and lentic waterbodies in river floodplains of France: a methodological tool for palaeoecological applications. Journal of Paleolimnology 35, 149-166.

Gandouin, E., Ponel, P., Franquet, E., Van Vliet-Lanoë, B., Andrieu-Ponel, V., Keen, D.H., Brulhet, J., Brocandel, M., 2007a. Chironomid responses (Insect: Diptera) to Younger Dryas and Holocene environmental changes in a river floodplain from northern France (St-Momelin, St-Omer basin). The Holocene 17, 331-347.

Gandouin, E., Van Vliet-Lanoë, B., Franquet, E., Andrieu-Ponel, V., Keen, D.H., Ponel, P., Meurisse, M., Brulhet, J., Brocandel, M., 2007b. Analyse en haute résolution de l'enregistrement de la transgression holocène dans un secteur subsident du littoral français: le bassin-marais de Saint-Omer (Pas-de-Calais, France). Géologie de la France 1, 11-32

Gehu, J.M., 1970. Carte de la végétation de la France, Lille n4. CNRS, Toulouse.

Heyvaert, F., 1980. Première contribution à l'étude palynologique des spectres récents dans les vases salées des estuaires picards (Somme et Pas-de-Calais). Bulletin de l'Association Française pour l'Etude du Quaternaire 1-2, 35-39.

Huisink, M., 2000. Changing river styles in response to Weichselian climate changes in the Vecht valley, eastern Netherlands. Sedimentary Geology 133, 115-134.

Jalut, G., Andrieu, V., Delibrias, G., Fontugne, M., Pages, P., 1988. Paleoenvironment of the valley of Ossau (French Western Pyrénées) during the last 27000 years. Pollen et Spores 3-4, 357-393.

Jelgersma, S., 1979. Sea level changes in the North Sea basin. In: Oele, E., Schuttenhelm, R.T.E., Wiggers, A. (Eds.), The Quaternary History of the North Sea. University of Uppsala, Uppsala.

Jones, R.L., Keen, D.H., 1993. Pleistocene Environments in the British Isles. Chapman \& Hall, London.

Lambeck, K., 1997. Sea-level change along the French Atlantic and Channel coasts since the time of the Last Glacial Maximum. Palaeogeography, Palaeoclimatology, Palaeoecology 129, 1-22.

Long, A.J., Innes, J.B., Kirby, J.R., Lloyd, J.M., Rutherford, M.M., Shennan, I., Tooley, M.J. 1998. Holocene sea-level change and coastal evolution in the Humber estuary, eastern England: an assessment of rapid coastal change. The Holocene 8, 229-247.

Mansy, J.L., Manby, G.M., Averbuch, O., Everearts, M., Bergerat, F., Van Vliet-Lanoë, B. Lamarche, J., Vandycke, S., 2003. Dynamics and inversion of the Mesozoï Basin of the Weald-Boulonnais area: role of basement reactivation. Tectonophysics 373, 161-179.

Ménot, G., Bard, E., Rostek, F., Weijers, J.W.H., Hopmans, E.C., Schouten, S., Sinninghe Damsté, J.S., 2006. Early Reactivation of European Rivers During the Las Deglaciation. Science 313, 1623-1625.

Metcalfe, S.E., Ellis, S., Horton, B., Innes, J.B., McArthur, J., Mitlehner, A., Parkes, A Pethick, J.S., Rees, J.G., Ridgway, J., Rutherford, M.M., Shennan, I., Tooley, M.J., 2000. The Holocene evolution of the Humber Estuary: reconstructing change in a dynamic environment. In: Shennan, I., Andrews, J.E. (Eds.), Holocene Land-Ocean Interaction and Environmental Change around the North Sea. Geological Society Special Publication, London, pp. 97-118.

Meurisse, M., Van Vliet-Lanoë, B., Talon, B., Recourt, P., 2005. Complexes dunaires et tourbeux holocènes du littoral du Nord de la France. Comptes Rendus Geosiences $337, \quad 675-684$

Meurisse-Fort, M., 2008. Enregistrement haute résolution des massifs dunaires Manche, mer du Nord et Atlantique. Le rôle des tempêtes. Publibook, Paris.

Morzadec-Kerfourn, M.T., 1974. Variation de la ligne de rivage armoricaine au quaternaire. Analyses polliniques de dépôts organiques littoraux. Mémoires de la société géologique et minéralogique de Bretagne, Rennes.

Morzadec-Kerfourn, M.T., 1985. Variations du niveau marin à l'Holocène en Bretagne (France). Eiszeitalter und Gegenwart 35, 15-22.

Munaut, A.V., 1967. Recherches paléo-écologiques en Basse et Moyenne Belgique. Acta Geographica Lovaniensia (Louvain).

Munaut, A.-V., Paulissen, E., 1973. Evolution et paléo-écologie de la vallée de la petite Nèthe au cours du Post-Würm (Belgique). Annales de la Société Géologique de Belgique 96, 301-348.

Munaut, A.-V., Sommé, J., Demolon, P., 1995. Tardiglaciaire (Alleröd) et Holocène ancien dans la vallée de la Scarpe à Douai (Nord de la France). Quaternaire 6, 167-172.

Nakagawa, T., 1998. Etudes palynologiques dans les Alpes françaises centrales et méridionales: histoire de la végétation Tardiglaciaire et Holocène. Ph. D. Thesis, Université Aix-Marseille III, Marseille, France.

Pastre, J.F., Leroyer, C., Limondin-Lozouet, N., Chaussé, C., Fontugne, M., Gebhardt, A., Hatté, C., Krier, V., 2000. Le Tardiglaciaire des fonds de vallée du Bassin parisien (France). Quaternaire 11, 107-122.

Pederson, D.C., Peteet, D.M., Kurdyla, D., Guilderson, T., 2005. Medieval Warming, Little Ice Age, and European impact on the environment during the last millennium in the lower Hudson Valley, New York, USA. Quaternary Research 63, 238-249.

Peglar, S.M., 1993. The mid-Holocene Ulmus decline at Diss Mere, Norfolk, UK: a year-by year pollen stratigraphy from annual laminations. The Holocene 3, 1-13.

Ponel, P., Coope, G.R., Antoine, P., Limondin-Lozouet, N., Leroyer, C., Munaut, A.-V., Pastre, J.F., Guiter, F., 2005. Lateglacial Palaeoenvironments and Palaeoclimates from Conty and Houdancourt, Northern France, reconstructed from Beetle remains. Quaternary Science Reviews 24, 2449-2465.

Ponel, P., Gandouin, E., Coope, G.R., Andrieu-Ponel, V., Guiter, F., Van Vliet-Lanoë, B., Franquet, E., Brocandel, M., Brulhet, J., 2007. Insect evidence for environmental and climate changes from Younger Dryas to Subboreal in a river floodplain at StMomelin (St-Omer basin, northern France), Coleoptera and Trichoptera. Palaeogeography, Palaeoclimatology, Palaeoecology 245, 483-504.

Reille, M., Andrieu, V., 1995. Late-Pleistocene and Holocene in the Lourdes Basin (western Pyrénées, France): new pollenanalytical and chronological data. Vegetation History and Archaeobotany 4, 1-21.

Reimer, P., Baillie, M.G.L., Bard, E, Bayliss, A., Beck, JW Bertrand, C..H., Blackwell, P.G. Buck, C.E., Burr, G.S., Cutler, K.B., Damon, P.E., Edwards, R.L., Fairbanks, R.G., Friedrich, M., Guilderson, T.P., Hogg, A.G., Hughen, K.A., Kromer, B., McCormac, G., Manning, S., Ramsey, C.B., Reimer, R.W., Remmele, S., Southon, J.R., Stuiver, M., Talamo, S., Taylor, F.W, van der Plicht, J.,Weyhenmeyer, C.E, 2004. INTCAL04 terrestrial radiocarbon age calibration. Radiocarbon 46, 1029-1058.

Scourse, J.D., Austin, R.M., 1995. Palaeotidal modelling of continental shelves: marine implications of a land-bridge in the Strait of Dover during the Holocene and Middle Pleistocene. In: Preece, R.C. (Ed.), Island Britain: A Quaternary perspective. Geological Society Special Publication, London, pp. 75-88.

Shennan, I., Andrews, J.E., 2000. Holocene Land-Ocean Interaction and Environmental Change around the North Sea. Geological Society, Special Publication, London.

Shennan, I., Lambeck, K., Horton, B., Innes, J., Lloyd, J., McArthur, J., Rutherford, M., 2000. Holocene isostasy and relative sea-level changes on the east coast of England. In: Shennan, I., Andrews, J.E. (Eds.), Holocene Land-Ocean Interaction and Environmental Change around the North Sea. Geological Society Special Publication, London, pp. 275-298.

Sommé, J., 1977. Les plaines du Nord de la France et leur bordure, étude géomorphologique. Ph. D. Thesis, Paris I, Lille, France.

Sommé, J., Munaut, A.V., Emontspohl, A.F., Limondin, N., Lefèvre, D., Cunat-Bogé, N., Mouthon, J., Gilot, E., 1994. The Watten boring - an Early Weichselian and Holocene climatic and palaeoecological record from the French North Sea coastal plain. Boreas 23, 231-243.

Starkel, L., 1991. Environmental changes at the Younger Dryas-Preboreal transition and during the early Holocene: some distinctive aspects in central Europe. The Holocene 1, 234-242.

Stuiver, M., Reimer, P.J., Bard, E., Beck, J.W., Burr, G.S., Hughen, K.A., Kromer, B., McCormac, G., van der Plicht, J., Spurk, M., 1998. INTCAL98 radiocarbon age calibration, 24,000 to 0 cal BP. Radiocarbon 40, 1041-1083.

Stuiver, M., Reimer, P.J., and Reimer, R.W. 2005. CALIB 5.0. [WWW program and documentation].

Ters, M., Delibrias, G., Denèfle, M., Rouvillois, A., Fleury, A., 1980. Sur l'évolution géodynamique du Marquenterre (Basse-Somme) à l'Holocène et durant le Weichsélien ancien: la série des dépôts marins et continentaux aux environs de Rue. Bulletin de l'Association Française pour l'Etude du Quaternaire 1-2, $11-23$

Törnqvist, T.E., Wallinga, J., Murray, A.S., de Wolf, H., Cleveringa, P., De Gans, W., 2000. Response of the Rhine-Meuse system (west-central Netherlands) to the last Quaternary glacio-eustatic cycles: a first assessment. Global and Planetary Change 27, 89-111.

Van der Woude, J.D., Roeleveld, W.,1985. Paleoecological evolution of an interior coastal zone: the case of the northern France coastal plain. Bulletin de l'Association Française pour l'Étude du Quaternaire 1, 31-39. 
Van Vliet-Lanoë, B., Gandouin, E., Meurisse, M., 2004. Évolution des niveaux marins quaternaires dans le Nord de la France: données nouvelles et mise au point. Sucellus 55, 1-16.

Van Zeist, W., Van der Spoel-Walvius, M.R., 1980. A palynological study of the LateGlacial and the Postglacial in the Paris Basin. Palaeohistoria 22, 68-109.

Vinchon, C., Gourry, J.C., Farjanel, G., Hervieux, D., Van Vliet-Lanoë, B., Baeteman, C., 2000. Evolution géologique du système côtier picard entre Berck et Merlimont au Quaternaire.Scénarios géoprospectifs de l'évolution dunaire. ONF-BRGM, Orléans.

Waller, M.P., 1993. Flandrian vegetational history of south-eastern England. Pollen data from Pannel Bridge, East Sussex. New Phytologist 124, 345-369.

Waller, M.P.,1994. Flandrian vegetational history of south-eastern England. Stratigraphy of the Brede valley and pollen data from Brede Bridge. New Phytologist 126, 369-392.
Waller, M.P., Long, A.J., 2003. Holocene coastal evolution and sea-level change on the southern coast of England: a review. Journal of Quaternary Science 18, 351-359.

Wimble, G., Wells, C.E., Hodgkinson, D., 2000. Human impact on mid-and late Holocene vegetation in south Cumbria, UK. Vegetation History and Archaeobotany 9, 17-30.

Ybert, J.P., Bissa, W.M., Catharino, E.L.M., Kutner, M., 2003. Environmental and sea-level variations on the southeastern Brazilian coast during the Late Holocene with comments on prehistoric human occupation. Palaeogeography, Palaeoclimatology, Palaeoecology 189, 11-24.

Yi, S., Saito, Y., Yanga, D.Y., 2006. Palynological evidence for Holocene environmental change in the Changjiang (Yangtze River) Delta, China. Palaeogeography, Palaeoclimatology, Palaeoecology 241, 103-117. 